UDC 930 Džat T.

Мирослав Павловић

Оригиналан научни рад

Универзитет у Новом Саду

примљено: 21. јун 2012

Филозофски факултет

прихваћено: 1. октобар 2012

Одсек за историју

mpavlovitch@yahoo.com

\title{
АНГАЖОВАНИ ИНТЕЛЕКТУАЛИЗАМ И ЕТИКА ОДГОВОРНОСТИ ИСТОРИОГРАФСКО ДЕЛО ТОНИЈА ЏАТА*
}

Сажетак: Рад анализира историографско дело америчког историчара енглеског порекла Тонија Џата (1948-2010.) са фокусом на специфичности његовог приступа историографији, интелектуалној историји и критеријумима етичког одабира. Издвојене су три фазе његовог стваралаштва, што је условило и структуру самог рада: студије марксизма, интелектуалне историје и јавни ангажман. Посебно је анализиран однос према марксизму и идеја дистинкције тзв. историјског стаљинизма и теоријског марксизма, на основу које је оптуживао водеће француске послератне интелектуалце за симпатије према тоталитаризму. Током последње фазе фокус је на Џатовој критици америчког интервенционизма и јеврејске политике у Палестини, али пре свега његовој критици вредности савременог света, током које се враћа идејама теоријског марксизма.

Кључне речи: Тони Џат, историографија, XX век, марксизам, левица, интелектуална историја, француски интелектуалци.

The responsibility toward history dispenses One of responsibility towards human beings

A. Camus

When the facts change, I change my mind. What do you do?

J. M. Keynes

Потребни су нам људи који супротстављање већинском мииљењу уздижу до нивоа врлине

Тони Џат

\section{Терет одговорности}

Тони Џат је био политички посвећен историчар, како се изразио Ерик Хобсбаум опраштајући се од пријатеља који је марширао другим путем. ${ }^{1}$ Био је

\footnotetext{
* Текст је настао као фазни резултат рада на пројекту Војвођански простор у контексту европске историје (број 177002) Министарства просвете и науке Републике Србије.
} 
социјалдемократа, није веровао у комунизам, али је највећи део своје каријере посветио студијама марксизма и француске левице, због чега је остао веома дуго маргинални историчар. Његова повезаност са политиком никако није банална, већ представља етичку потребу ангажованог интелектуалца. Теме које је обрађивао чине се маргиналним, долазе из другог плана највећих процеса XX века и на први поглед заобилазе мејнстрим историјске науке. Студије комунизма ограничавао је на периферију, француску левицу, Леона Блума; студије о Европи на интелектуалне покрете, заборављене личности, европску периферију. Џат је тим приступом контекстуализовао историјска сазнања, градећи слику једног другог XX века. Његов интелектуализам прошао је кроз три фазе. Најпре је себе пронашао у једној теми, попут доброг занатског историчара, продубљујући емпиријски рад у циљу систематизације знања. Затим је у наредној фази ширио тематски опсег на читав век, покушавајући изнад свега да разуме. Није се задовољавао интерпретацијом прошлости, општа места је по правилу заобилазио, постижући оригиналност интерпретације, анализирајући уједно идеје које су покретале идеологије и процесе. У последњој фази анализа је прелазила у критику, док је Џат осећао спремност да кризу капитализма посматра кроз двадесетовековно залеђе. Његова критика капитализма, глобализма и пре свега вредности на којима почива савремени свет резултат је разумевања века коме је посветио живот. Та последња фаза обележена је борбом са смрћу која је свакодневно вребала и којој се одупирао све док није презентовао своја размишљања о веку коме је припадао. То је био његов терет одговорности, дужност према науци и свету, етички идеал и последња фаза којој тежи један историчар.

Тони Џат је читав свој радни век посветио интелектуалној историји, клонећи се историје идеја и социјалне историје, инсистирајући на идеји о „историји разговора“, где историчар доноси судове на основу питања ангажованости, одговорности и избора. ${ }^{2}$ Такав приступ условљавала је његова преокупација идејом истине, као основним интелектуалним изазовом XXI века. Истина, као и етика упркос плурализму никако не могу бити релативизоване, иако не постоји универзална истина постоји јединствен морал, универзална вредност на коме почива једно друштво. Друштво без морала осуђено је на пропаст. Појам истине своди на појединачни ангажман и посматра га кроз две димензије. Историјска истина произлази из задатка историчара да теоретише прошлост, где увек постоје различити начини да се мисли о прошлости. Она зависи од аутентичности и научног поштења. Истина која је условљавала Џатов ангажман представља малу истину, одговорност интелектуалца да објасни, нарочито савременог историчара кога посматра у задатку просвећивања. Мале истине како то закључује Тимоти Снајдер представљају Золин ангажман у Драјфусовој афери и Џатов око рата у Ираку. ${ }^{3}$ Иако велики противник наративне историографије, у својим првим радовима управо

\footnotetext{
${ }^{1}$ Eric Hobsbawm, After the Cold War, London Review of Books, Vol. 34, No. 8, London 2012

${ }^{2}$ Tony Judt, Past Imperfect. French Intellectuals, 1944-1956, Barkley-Los Angeles-Oxford 1992, 10.

${ }^{3}$ Велика истина сходно њиховом гледишту може бити само револуција. Мале истине не мењају свет али га чине бољим. Tony Judt, Timothy Snyder, Thinking the Twentieth Century, New York 2012, 14-17.
} 
комбинује традиционални приступ са броделовским. Веома брзо почиње да инсистира да задатак историчара није да преради, преприча прошлост, већ да објасни, а изнад свега да разуме. Разумевање као највиши императив историчаревог заната удаљава га од социјалне историје, јер га не занимају околности у којима су интелектуалци деловали. Супротна крајност, историја идеја не пружа одговоре који би задовољили историчара, већ више филозофе, социологе, политикологе. Џата не занима Сартрова филозофија, интелектуална ангажованост, већ пре свега Сартрово ћутање о најстрашнијим феноменима XX века, фашизму и стаљинизму. Зато свој приступ дефинише интелектуалном историјом. Социјална историја водила га је ка маргиналним темама, док је изазов епохе полако усмеравао историчаре ка теоријама модернизације (које је сматрао неисторијским и чија је идеја прогреса била сувише телеолошка) или културолошким студијама. ${ }^{4}$ Критиком послератне француске интелектуалне јавности Џат је добио светски публицитет, после чега је уследио његов ангажман али и оспоравања да се сам није ослободио особина које толико критикује код „својих интелектуалаца“. Подстицај за сопствени ангажман оправдава књигом снажног наслова Терет одговорности, где кроз интелектуализам, одговорност и ангажованост креира својеврсног homo ethicus-a. Поштење Леона Блума, морал Албера Камија и реализам Рејмона Арона, нису само особине којима је узвисио тројицу интелектуалаца направивши пандан посрнућу Сартра, Симон де Бовоар... то су особине за које је веровао да их сам поседује.

Џат је био моралист! Инсистирао је на праведности и у преиспитивању како сам каже долазио до солипсизма. ${ }^{5}$ Двадесети век је посматрао као време зла, инсистирајући на избору. Избору тридесетих када је фашизам претио, избору педесетих када се требало одрећи комунистичке догме, избору деведесетих и касније против америчког империјализма и концепта неолиберализма. Међутим XX век је век идеологија, према којима је као историчар и интелектуалац захтевао одређење. Џат пречесто суди због тишине и својеврсне интелектуалне амбивалентности, због лажи или слабости интелектуалаца да се покају односно одрекну својих пређашњих уверења. То је суштина његовог сукоба са Ериком Хобсбаумом, коме је замерао на доследности, доследности у заблуди вере у једну утопију. Џат није био спреман да раздвоји комунизам од марксизма, односно идеологију од њене реализације по совјетском моделу. Иако прихвата марксизам за племениту идеологију са трагичном реализацијом, правећи јасну дистинкцију од фашизма, заступа тоталитаристичко објашњење Хане Арент. ${ }^{6}$ Одређење према посматра као етичко питање, сматрајући да XX век није дозвољавао неангажованост, јер је пречесто само ћутање значило одређење. Када је реч о одређењу за, идеологије пређашњег века посматра као веру и наду. Веру јер се посвећеност често граничила са религијским доживљајем, а наду јер су идеологије покретале масе. С окончањем Хладног рата и „крајем историје““, наивном

\footnotetext{
${ }^{4}$ T. Judt, T. Snyder, Thinking the Twentieth Century, 200-220.

${ }^{5}$ Toni Dzad, Teško zemlji, Beograd 2011, 9.

${ }^{6}$ О идеји тоталитаризма видети: Hana Arent, Izvori totalitarizma, Beograd 1998.

${ }^{7}$ О томе видети: Frensis Fukujama, Kraj istorije i poslednji čovek, Podgorica-Banja Luka-Beograd 2002.
} 
синтагмом америчке самоуверености, нестали су покретачи маса, нестало је идеализма. Одсуство вредности као пратећи елеменат идеологија и честу појаву у $\mathrm{XX}$ веку, посматра не само кроз етичку раван већ као примарно питање савременог поретка. Тешко земљи биће његов повик када епистемолошки дође до закључка да је идеологија усмерена против хуманости, јер прагматизам и материјализам по њему нису својствени људској природи. Није дозвољавао да се фашизам посматра као обележје једне епохе као што није могао пристати да је холокауст проблем јеврејских жртава и немачких злочинаца. Његов панегирик као и критика најснажније су упућени генеращији 1905. најутицајнијим интелектуалцима века. Жан Пол Сартр, Хана Арент, Рејмон Арон, Артур Кестлер сукобљавали су се са свим трагичним изборима века, и упркос Сартровој неангажованости, сви остали су упозоравали на претећу опасност. Сартр је као одговор на епоху и вредносне изазове прибегао егзистенцијалистичкој филозофији. ${ }^{8}$

Последњу фазу Џатовог рада и посебно његовог активизма обележила је борба за алтернативу. Марксизам је остајао централна тачка његових размишљања. Полазећи од идеје Мориса Мерло Понтија да одрицање од марксизма као филозофије историје представља сахрањивање разума у историји није могао да се помири са констатацијом Франсоа Фиреа (који је веома утицао на његова размишљања) да је идеју другачијег друштва данас немогуће постићи. Остаје доследан идеји утопије која производи хуманије друштво. По чему се онда Џат разликује од интелектуалаца које толико критикује? Никако по вери у утопију, утопијски космополитизам како су му критичари спочитавали. ${ }^{9}$ Марксизам почиње да посматра као теорију, ослонац не само социјалиста и комуниста, већ читаве левице. Без марксизма или теорије која би га заменила не постоји могућност изградње социјално одговорног друштва, где прибегава Марксовим тезама о Фојербаху истичући идеју разумевања света како би се променио. Џат није понудио алтернативу у виду нове идеологије, нити је то покушавао, јер је она у данашњем свету неуочљива. Међутим одупирао се нападима да је својим моралисањем остајао на пољу критике не нудећи алтернативу. Промена поретка коју је заговарао, није могућа без делегитимације неолибералног система којој је он толико пажње посветио. Направио је почетни корак. Његов став о алтернативној друштвеној теорији заснованој на марксистичким идејама сличан је идејама Хобсбаума кога је раније излагао оштрој критици. ${ }^{10} \mathrm{C}$ друге стране Џат прибегава социјалној теорији од које је толико бежао током читаве претходне фазе свог рада. Међутим, треба разликовати његову резервисаност према социјалној историји од социјалне теорије коју заговара. Првој је замерао на опсесији методима и техникама и одсуству теорије, нарочито са стерилном теоријом модернизације док је под друштвеном теоријом подразумевао идеолошки ослонац. Џат уосталом заступа примат политичке историје, односно историје идеја, идеологија; једноставније,

\footnotetext{
${ }^{8}$ T. Judt, T. Snyder, Thinking the Twentieth Century, 50-60.

${ }^{9}$ Samuel Moyn, Intellectuals, Reason, and History: In Memory of Tony Judt, H-France Salon, Volume 4, Issue

2, No. 3; Samuel Moyn, On the Genealogy of Morals, The Nation, 16. April 2007.

${ }^{10}$ Eric Hobsbawm, How to Change the World. Reflections on Marx and Marxism, London 2011.
} 
доминантних друштвених фактора. ${ }^{11}$ Због тога остаје доследан и у науци и у јавном ангажману. Сматрао је да социјалдемократија почива на марксистичким основама, што је доказивао тврдњом да је са пропашћу комунизма пропао и систем политичке левице, и да у политици више није било битно одређење у складу са политичким спектром док су социјалдемократи спроводили програме који су само деценију раније оштро нападали. Уочљиво је и заступање кејнзијанских метода, али Џат није једноставно био Кејнзијанац, он је веровао у етичку, хуману кејнзијанску економску теорију. Разлику између Кејнза и Хајека доживљавао је као одабир између државе благостања каква је постојала пре Регана и Тачерове и сурову експлоатацију засновану на нехуманим принципима савременог неолиберализма. Демократија без своје социјалне компоненте за њега је демократија без смисла, јалова демократија. Питајући се има ли социјалдемократија будућност, констатује да би то могла бити само социјалдемократија страха, као идеалистичка концепција, јер не треба заборавити да је и сама социјалдемократска идеја рођена у понору који је капитализам доживео. ${ }^{12}$ Држећи се етичких принципа Џат током своје три научне фазе мења критеријуме на основу којих суди као историчар и интелектуалац. У том погледу најкарактеристичнији је однос према марксизму.

\section{Марксизам и француска левица}

Одабир између две доминантне идеологије XX века, фашизма и марксизма за историчара интелектуалне мисли није био нарочито тежак, јер како сам истиче марксисти полазе од концепата, од идеја којима мењају свет, док фашисти немају концепт, имају ставове. Марксизам није била идеја њему блиска, најпре због нереалистичности обећања која је социјализам нудио. Џат је склон да поставља питања о моралним начелима нужности социјализма, о неизвесностима будућности и жртви коју захтева за такву будућност. Марксизам у основи посматра као телеолошку идеологију, која се без вере не може прихватити. Такође, није био спреман да прихвати марксистичку друштвену теорију, посебно инсистирање на економским основама. Међутим левичарска уверења јесу била његов избор, хуманизам и секуларизам као највиши домет њене друштвене мисли. Ипак историјски приступ марксизму није једнозначан. Додуше, често се одређује према марксизму, као према алтеритету, нарочито када је у питању идеја социјалдемократије. Како је већ истакнуто, сматра да без марксизма, без одређења према марксизму, према радикалној (револуционарној) левици, ни сама умерена левица нема простора за битисање. Није му ни примамљива идеја социјалистичког колективизма. Левица привлачи Џатову пажњу са два аспекта, као покрет и као интелектуални изазов. На одабир студија утицала је идеја о култури левице, о генерацијама посвећених појединаца, нарочито послератних левичара коју ће

\footnotetext{
${ }^{11}$ Tony Judt, A Clown in Regal Purple: Social History and the Historians, History Workshop Journal, No. 7, Oxford 1979, 66-94.

${ }^{12}$ Tony Judt, What is Living and What is Death in Social Democracy? The New York Review of Books, December 17, 2009.
} 
назвати Сартровом генерацијом. Појаву левице посматра као последњи стадијум ничеовске смрти божанства, као врхунац либералне секуларне традиције. Ни ту не одступа од основне идеје водиље етичког приступа историографији, позивањем на утилитарну етику Џона Стјуарта Мила и етичке императиве Имануела Канта. Зато за највеће достигнуће европске левице у последњој четвртини XIX века издваја секуларни приступ етици, друштву, друштвеним променама, историји... Уосталом, то су уједно и идеје Друге интернационале. ${ }^{13}$

Посебно питање представља Џатов приступ улози личности у историји, нарочито у светлу његовог инсистирања на индивидуализму. Само супротстављање колективистичким идеологијама не представља проблем код одређења према колективној одговорности. Иако снажан индивидуалиста, помало контрадикторно заступа идеју морала који не може бити заснован на индивидуалним уверењима, јер би то водило друштвеном хаосу у смислу Хобсовог homo homini lupus est. За Џата човек је друштвено биће, али је његова одговорност индивидуална. Како критикује тачеристичко гледиште о непостојању друштва, негирању сваке заједнице веће од породице, тако се супротставља тоталитаризмима. Однос према тоталитаризму заснива на идеји о антитоталитаристичком покрету, захтева одређење. Марксизам је једно, совјетски комунизам је тоталитарна идеологија и сваки марксиста, сваки комуниста који се није јасно дистанцирао нашао се на његовој оптуженичкој клупи. Из сличних мотива супротставиће се и Сартровој идеалистичкој филозофији (а није далеко ни Де Бовоар) која идејом о постојању сопственог идентитета само кроз другог па према томе и немогућности прихватања моралних начела избегава питање одређења и занамарује сваку индивидуалну одговорност. Улогу личности у историји зато не посматра у смислу Карлајлових хероја, али им даје известан терет одговорности. Сам историјски метод за који се одлучио инсистира на индивидуалности и изнад свега одговорности, што интелектуалце издваја из социјалне средине. Његова анализа се своди на питања избора и одговорности према начињеном избору, што апстрахује све изван когнитивног домена личности. Међутим, метод интелектуалне историје није потпуно примењен у првој фази када је проучавао марксизам и левицу. Она обухвата период од доктората 1976. до 1986. када је издата трећа и последња књига овог корпуса. ${ }^{14}$ У том периоду настала је и његова критика социјалне историје (1979.). Управо те године завршио је студије о социјализму у Прованси. Монографија која је резултат тог рада типичан је пример његовог експеримента броделовског типа. Могло би се констатовати да је реч о неуспелој, готово хибридној примени идеја аналиста на традиционалну историографију, једној комбинацији од социјално-економских до климатских фактора уклопљених у наративни приступ. Џат није могао да се одрекне политичке историје, због чега и напушта социјалну историју, где уосталом није успео да постигне оригиналност. Следећа монографија исказује извесну дистанцу и

\footnotetext{
${ }^{13}$ T. Judt, T. Snyder, Thinking the Twentieth Century, 202, passim.

${ }^{14}$ Tony Judt, La reconstruction du parti socialiste: 1921-1926, Paris1976; Isti, Socialism in Provence 18711914. A Study in the Origins of the Modern French Left, New York-London 2011 (1979 $)$; Isti, Marxism and the French Left. Studies of Labour and Politics in France, 1830-1981, New York-London 2011 (1986 ${ }^{1}$ ).
} 
представља прелазни период где се види његово трагање за методом. С обзиром на непостојање јединственог приступа може се са извесним опрезом говорити о тенденцијама. Заокупљеност ауторитетима постаје све израженија, уосталом констатоваће да је француска левица одувек била заокупљена питањем ауторитета и дефинисањем природе ауторитета. ${ }^{15}$ Иако ће издвојити Жана Жореса, Жила Геда или Леона Блума, али и читаву плејаду локалних „хероја“ не може се говорити о тенденциозности приступа већ традиционалном устројству француског политичког система око политичке снаге појединца.

Значајнији је његов аутаркични приступ левици, коју посматра као corpus separatum, усмеривши се на организационе проблеме, чланство, бирачко тело, ресурсе. Пише историју једне партије, у Француској или Прованси, у једном веку, у читавом периоду њеног постојања. Ништа не мења ни када од једне настану две партије (1920.), без упуштања у сложености политичког система постаје мајстор апстракције. Између социјализма у Прованси и социјализма у Француској јасно се уочава његов раскид са аналистима, па чак и политичком школом анала доминантном тих година. ${ }^{16}$ Џатов приступ постаје сложенији ако се посматра феноменолошки, јер у његовом фокусу није партија како се то наизглед чини, већ покрет. Иако наизглед терминолошке нијансе суштински је у питању огромна разлика. Полази од хипотезе о екстремизму на француском селу и посвећује се проучавању узајамне повезаности ситног сељачког поседа на француском југу и марксистичких идеја. Ту постиже оригиналност и развија идеју о „култури левице“. Џат прати две тенденције, интелектуални покрет и локалну организацију, при чему подразумева распрострањеност идеологије у маси. Одбацује идеје о насумичном гласању, о привременом, несуштинском припадању левици, припадању без разумевања. Истиче идеју континуитета, о развоју самосвесне револуционарне доктрине која доминира француском политичком сценом од краја XVIII века све до дубоко у XX век. Традиција левице у Француској, развијена из теоријске дебате и радикалне политичке акције изградила је посвећеност левици која се преноси генерацијама. ${ }^{17}$ Посматра сељаштво као агенс социјалних промена и фокусира се на појаву руралног социјализма. Џат заправо тражи корене европске левице, јер ће између теорија о традицији екстремизма и руралног социјализма издвојити социјализам на малом сеоском поседу, као уникатан модел. Не само да одбацује екстремистичке теорије на француском примеру, већ и саму идеју о сељачким револуцијама у неиндустријским друштвима. Рурални социјализам француског југа утемељује као покрет настао на идеологији и уверењу, не ради радикалне акције против државе, већ у циљу борбе за сопствена права, као колективни утилитаризам. Коначно, социјализам посматра као најјачу снагу социјалне кохезије. ${ }^{18}$ Овакво

\footnotetext{
${ }^{15}$ T. Judt, Marxism and the French Left, 4.

${ }^{16}$ Питер Берк, Франиуска историјска револуција: икола „Анала“ 1929-1989, Нови Сад 2011.

${ }^{17}$ T. Judt, Marxism and the French Left, 1830-1981, 1-23; T. Judt, The Development of Socialism in France: The Example of the Var, The Historical Journal, Vol. 18, No. 1, Cambridge 1975, 55-83.

${ }^{18}$ T. Judt, The Origins of Rural Socialism in Europe: Economic Change and the Provençal Peasantry, 18701914, Social History, Vol. 1, No. 1 (Jan. 1976.), 45-65.
} 
становиште доводи га у сукоб са заговорницима теорија о одабиру екстрема, али остаје доследан у идеји аутохтоне левице. ${ }^{19}$

Социјализам у Француској у XX веку посматра као покрет између два рата и као марксистичку идеју после Другог светског рата. Готово потпуна незаинтересованост за комунизам оставља многа питања отворена, посебно односа две партије и промена структуре левице, њене руралне базе пре свега, нарочито са губитком бирачког тела кроз које су прошли француски социјалисти. Микро студије којима је проучавао деветнаестовековну историју покрета напушта и почиње да примењује метод интелектуалне историје. То је најочигледније код приступа послератним француским левичарским интелектуалцима, али и током међуратне историје где се фокусира на улогу Леона Блума. Међуратни социјализам оличен у Социјалистичкој партији представља реални социјализам, питање избора, етичког одређења. Персонификује реалну политичку снагу, која се сходно Блумовом програму интегрисала у систем, како би освојила власт а тек у наредној фази концентрисала на промену. Идеја социјализма у том периоду суочена је са притисцима и са левице и деснице. Џат посебну пажњу поклања управо тим прекретницама, интеграцији 1924. и почетку Блумове доминације 1928, као и доласку на власт 1936. Управо због тих својевсних ломова, посматра програм партије, његове промене и основне идеје водиље. Посебно га занима однос према другим партијама и изнад свега морални избори тридесетих година. Послератни марксистички покрет како га назива, апстрахује од страначке организације са фокусом на однос према совјетском моделу, или како ће то нагласити историјском стаљинизму за разлику од теоријског марксизма. Реч је о својеврсном парадоксу, замци у коју су упали француски интелектуалци својим аподиктичким ставом према „држави пролетаријата“. Занима га пре свега однос према имагинарној реалности, према систему каквим су га замишљали, с једне стране капитализам као историјски и економски систем и социјализам као политичка и етичка идеја. ${ }^{20}$

Сам Џатов однос према марксизму је веома изнијансиран и захтева подробнију анализу. Најпре марксизам посматра као покрет у XIX веку, са акцентом на рурални социјализам како би нагласио његову аутохтоност. У проучавању XX века најпре његову пажњу привлачи социјалистичка партија као странка система односно социјалдемократска идеја, док комунизам посматра као револуционарну левицу према којој се одређује, и која заслужује поверење и признање због своје антифашистичке борбе у светлу јасних моралних избора. У другој половини века теоријски марксизам остаје синоним за хуману идеологију према којој се социјалдемократија одређује у изградњи савремене државе социјалне бриге. Историјски стаљинизам повезује са комунистима, издвајајући совјетски модел као репрезентативан, и као матичан у односу на остале подружнице. Европски комунизам (до 1956. sic!) зато је само наличје стаљинизма, док широку

\footnotetext{
${ }^{19}$ T. Judt, Socialism in the French Countryside: A Reply, The Historical Journal, Vol. 21, No. 3 (Sep. 1978.), 693-695.

${ }^{20}$ Tony Judt, Past Imperfect. French Intellectuals, 1944-1956, 159-170; T. Judt, The French Socialist and the Cartel de Gauches of 1924, Journal of Contemporary History, Vol. 11, No. 2/3 (Jul. 1976.), 199-215; T. Judt, Marxism and the French Left, 115-239.
} 
подршку коју је добијао у Француској посматра као некритичко припадање. Коначно, када историјски стаљинизам нестане са политичке сцене Џат доследно подржава марксизам као идеју и као идеологију хуманости. Некритичко припадање као посебна фаза његових студија марксизма условила је и јединствен приступ афирмацијом интелектуалне историје.

\section{Џатова интелектуална историја}

Несумњиво је да је Тони Џат јединственошћу метода тежио оригиналности, али основно питање је колико се његова интелектуална историја разликује од историје идеја и коначно какав је њихов однос? Употребљен је етички метод, јер су основни критеријуми како је већ истакнуто, питања избора, одговорности за тај избор и ангажмана. То даље сугерише да у фокусу истраживања нису идеје, интелектуална стремљења, филозофска начела, већ политички активизам. Иако је тешко избећи поређења са историјом идеја, разлике ипак постоје, али се намеће још једно питање, проблем таквог приступа. Просуђивање на основу избора захтева и одговор о референтној тачки, афирмише Сартрово питање Камију на основу ког морала доноси суд, или у Џатовом смислу чак и пресуду. Етички критеријуми који су постављени занемарују читав спектар других критеријума, јер однос према, припадање идеологији, изградња става интелектуалне јавности знатно су сложенији проблеми од моралног избора. Коначно, занемарене су и околности у којима се прави избор, историјско искуство и шире друштвено значење, можда чак и колективна свест.

Француским интелектуалцима посвећене су две књиге, замишљене као апсолутне категорије, као критика и парадигма. ${ }^{21}$ Настале су током деведесетих (1992. и 1998.), читаву деценију после последње књиге о марксизму. Иако је током те деценије сам Џат био посвећен студијама источне Европе антиципирајући историјски след догађаја, сама тема његових студија после слома комунизма делује неуобичајено и увелико закаснело. Упркос томе, у питању је дело које му је донелу славу и уврстило га међу најрелевантније америчке историчаре, а уједно и пружило кредибилитет за озбиљнији јавни ангажман. Џат никад неће признати да је марксизам неактуелан, чак и одуство левичарске идологије за њега је само привремено. Монографија о француским интелектуалцима представља дубинску анализу темељних интелектуалних достигнућа XX века. То је књига о последњим изазовима париске интелигенције, тачније последњих дванаест година (1944-1956.) после којих Париз више неће бити интелектуална престоница света. Лево оријентисана француска интелектуална јавност, чак и после своје епохе наставиће да интригира и заокупља пажњу интелектуалне јавности, филозофија и друштвени ангажман Сартра, Симон де Бовоар, Малроа, Мунијеа, Франсоа Моријака... Њихов утицај у светској јавности, како то Џат истиче биће снажнији од утицаја другог ешалона француских интелектуалаца, следеће генерације (Франсоа Фире, Мишел

\footnotetext{
${ }^{21}$ Tony Judt, Past Imperfect. French Intellectuals, 1944-1956, Barkley-Los Angeles-Oxford 1992 ${ }^{1}$; T. Judt, The Burden of Responsibility. Blum, Camus, Aron, and the French Twentieth Century, Chicago-London 1998 ${ }^{1}$.
} 
Фуко, Жак и Мона Озуф, Ени Кригел, Морис Агилон, Мишел Перо, Жак Дерида). Међутим, Џат буди реминисценције на заборављене делове њихових биографија и њиховог ангажмана. ${ }^{22}$ „Прошлост је друга земља“ и „време је узнемирујуће огледало,“ парадигме су којима описује то заборављено искуство.

Између два мита, о француским интелектуалцима и о универзалном филокомунизму, Џат анализира последњи, тзв. „издају интелектуалаца“ која не може остати у сенци првог мита. То су питања која он оставља отвореним у својим закључцима. Најпре интелектуалци о којима суди су део историје са властитим историјским искуством који су осећали одговорност према свету коме припадају. Иако констатује да постоји извесна девалуација идеје одговорности, не може се занемарити њихов утицај на ширење разума у смислу тираније интелигенције. ${ }^{23}$ Овде је реч о једном делу интелигенције, свакако најутицајнијем, на челу са Сартром, који су припадали или симпатисали широки дијапазон левице и који су у каснијем периоду или ћутали о својој прошлости а свакако нису били спремни да је се одрекну. Основни проблем Џатовог приступа је још једна његова апстракција. Пошто симпатије према левици изједначава са „историјским стаљинизмом“ оптужује интелектуалце за подршку тоталитарном систему. С друге стране, и ту нијансу пажљиво истиче, интелектуалци се опредељују према утопији, према реализацији система утемељеног на принципима марксистичке филозофије и одбијају да критикују совјетски модел, претпостављајући да диктатура пролетаријата не може бити лоша за сам пролетаријат. Ова већ дијалектичка категорија их доста дуго наводи на слепу подршку, подршку из уверења, свакако утопијског, да су сведоци стварања једног хуманијег света. У својој истрајности интелектуалци су правдали злочине и репресију и одбијали да суде, речима Де Бовоар, „како поверовати да је широка пролетерска база на којој почива режим у Москви заправо бирократска диктатура, како је онда била у стању да мобилише континент, порази нацисте и спаси Европу од фашизма?“ 24 Интелектуалци су били у заблуди, али Џат суди тенденциозно. Посматрани период је ограничен на раздобље до 1956, а потпуно је занемарено њихово напуштање подршке совјетском моделу касније, као и специфичности еврокомунизма. Даље захтева одрицање од сопствене прошлости, али подршка стаљинизму како је назива није значила њихово институционално припадање, већ изнад свега идејни и етички избор заснован на учењима марксизма, за која су поверовали да се реализују у пракси. Схватањем да

\footnotetext{
22 Утицај француске интелигенције није занемарив ни у каснијем периоду, посебно идеје постструктурализма, постмодернизма... али француска интелигенција закључује Џат живи по целом свету само више не у Паризу. Т. Judt, Past Imperfect, 299; T. Judt, Paris Was Yesterday, New York Review of Books, March 11, 2010; T. Judt, "We Have Discovered History": Defeat, Resistance, and the Intellectuals in France, The Journal of Modern History, Vol. 64 (Dec. 1992.), 147-172.

${ }^{23}$ Џат овде мисли на улогу интелигенције против политичке олигархије која изврће реалност, где је задатак интелигенције да образује масу у циљу очувања и утемељења демократије. Несумњиво XX век посматра као век интелигенције, који је започео Золиним ангажманом током Драјфусове афере. Француска се тада, како закључује поделила на интелигенцију која је подржавала истину, правду и људска права и део који је истицао славу, нацију и домовину. Tony Judt, Past Imperfect, 293-319; T. Judt, Reappraisals. Reflection on the Forgotten Twentieth Century, New York 2008 ${ }^{1}, 12$.

${ }^{24}$ T. Judt, Past Imperfect, 161.
} 
реализација нема везе са марксистичком догмом утихнула је и подршка. Друго, питање терора, свакао осетљивије, које захтева одговор да ли су интелектуалци подржавали терор, што се не може закључити, али многи јесу остали слепи верујући да је у питању „револуционарни терор“. И у овом случају занемарује француску револуционарну традицију. Такође, пренебрегава и њихово, како сам истиче ужасно искуство са фашизмом, што их је усмеравало да се вежу за левицу. ${ }^{25}$ Овде сам Џат има проблем са избегавањем социјалне историје, јер не објашњава везу интелигенције и друштва. Припадање је свакако најспорније за Џата, али шта замерити једном марксисти и комунисти, какав је био Ерик Хобсбаум који се никад није одрекао својих веровања, али је осудио стаљинизам?

Пре одговора на ово питање потребно је анализирати Џатове даље интелектуалне студије (наредних десет година), низ ауторских текстова које ће сабрати у зборник и публиковати $2008 .{ }^{26}$ Реч је о космополитским интелектуалцима европске периферије. Посебно га је привукла појава бриљантних умова са географског простора не само континенталне, већ друштвене, националне периферије, делом и друштвене маргине, као феномен XX века. Већина су комунисти или из источног лагера, али не нужно. Њих не посматра као Арона, Блума или Камија, као моралне дивове, већ као покајнике, који су најснажније допринели делегитимизацији система из којег су потекли или коме су припадали. Несумњиво, по његовом етичком мерилу, њихово покајање екскулпирало је живот у греху, али је значајније ослањање на њихово дело. Реч је о Лешеку Колаковском, Чеславу Милошу, Милану Кундери, Артуру Кестлеру, Примо Левију. Џатов однос према интелектуалцима јасно се уочава на примеру његовог разумевања Колаковског када закључује да се „марксизам као доктрина не може одвојити од политичких покрета и система до којих је довео““27 Ту се пре свега ослања на идеју самог Колаковског да се марксизам не може спасити од његове дисторзије у рукама Стаљина и Лењина. ${ }^{28}$ То је научно поткрепљење тврдњама о историјском стаљинизму у који тенденциозно смешта француске интелектуалце. Међутим, исти критеријум примењује и на еврокомунизам, што је већ историјски изузетно тешко доказиво, с обзиром на дистанцирање од стаљинизма. Џат наставља да оптужује за нечисту савест и да напада сваки вид социјализма који се не може по његовом гледишту (које такође преузима од Колаковског) спасити мана марксизма, а овај опет од неуспеха комунизма, као што се комунизам не може спасити сопствених злочина. ${ }^{29}$ Код критике Хобсбаума у истом маниру одржава конфузију између марксизма и комунизма. Хобсбаумов комунизам за њега има мало везе са марксизмом, осим у домену теоријског приступа историографији, закључујући да је његово припадање Комунистичкој партији опстајало јер му није било од значаја. Овај изазов старијем колеги појачава називајући га „комунистичким мандарином... који није био спреман да се суочи са моралном дилемом и зло назове правим

\footnotetext{
${ }^{25}$ На овим аргументима дугујем колеги мр Миливоју Бешлину, на чему му свесрдно захваљујем.

${ }^{26}$ T. Judt, Reappraisals. Reflection on the Forgotten Twentieth Century, New York $2008^{1}$.

${ }^{27}$ T. Judt, Reappraisals, 133.

${ }^{28}$ Видети: Lešek Kolakovski, Glavni tokovi marksizma I, II, III, Beograd 1985.

${ }^{29}$ T. Judt, Reappraisals, 136.
} 
именом.“30 Између Хобсбаумове доследности и моралног избора стоји другачије разумевање ове двојице интелектуалаца, теорије марксизма и комунистичког покрета којима је потоњи припадао, јер Хобсбаум никада неће признати подударност стаљинизма и комунизма, као што неће престати како то сам истиче да осуђује и да се бори против друштвене неправде, јер „свет неће сам од себе постати боље место“. ${ }^{31}$

У својој другој књизи о француским интелектуалцима Џат се вратио питању „мита о интелектуалцима,“ покушавајући да лоцира њихову улогу у друштву између 1930. и 1970. Полазећи од идеја Жилијена Бенде о јавном ангажману као задатку интелектуалаца у потрази за правдом и истином у циљу заштите индивидуалних права, Џат се интересује за идеолошке дефиниције које су обесмислиле Бендине захтеве. Уводи појам политичке неодговорности којим описује заборављање прошлости и селективно памћење које је интелектуалну одговорност свело на припадање не покрету, већ припадање ради припадања (per se). Морална хипокризија допуштала је и радикалан раскид са прошлошћу и рапидну промену уверења, која је десничаре претварала у левичаре и обратно. Читав овај период, закључује карактерише политичка ангажованост. Остајући доследан методама интелектуалне историје интересују га унутрашњи пориви као покретачи на акцију, сводећи ангажман на питања избора и одговорности. Јавни ангажман не може бити питање колективних стремљења, већ индивидуални морални императив, и само такав ангажман поседује вредносни елеменат. Зато, у складу са Бендиним интелектуалним нормативом поставља питање има ли данас још интелектуалаца? Али интелектуалаца као „људи у тамним временима“ како карактерише Блума, Камија и Арона. Џат се поистовећује са реализмом Рејмона Арона који инсистира на ултимативном разуму и апсолутном знању као и свести о плуралности. На његовој посвећености веберовским разматрањима разумевања, свести и избора, али изнад свега цени Аронову одговорност према субјекту истраживања и сопственој епоси. ${ }^{32}$

Врхунац методолошког приступа остварује монографијом о послератној Европи, својеврсним ремекделом, где показује ширину ерудиције и интелектуализма. Јединством приступа помера границе политичке историје и уноси као и увек интригантну нијансираност посматрања. Никако не тежи апсолутној објективности, већ истиче да је реч о персоналној интерпретацији. На најбољи могући начин овде показује да политичка историја никако није традиционално схватање историографије. Лајтмотив којим се руководи јесте табу. Пише о ономе о чему се ређе ћути, о поимању холокауста, истребљењу Јевреја, страхотама у бројкама, интригира, упозорава и изазива непријатна осећања. Џат пре свега подсећа на потиснуте тренутке историје европских нација, подсећа на неморал, како се не би заборавило, јер само сачувана сећања могу гарантовати обновљену хуманост на континенту. Оживљава прошлост која опомиње, као терет

\footnotetext{
${ }^{30}$ T. Judt, Reappraisals, 116-128.

${ }^{31}$ Erik Hobsbaum, Interesantna vremena. Jedan život u dvadesetom veku, Podgorica 2005, 380.

${ }^{32}$ T. Judt, The Burden of Responsibility, 1-27, 140-144, 181-2; Julien Benda, Izdaja intelektualaca, Zagreb 1997.
} 
одговорности, као захтев за суочавањем са злочинима, а колико год се постављале као жртве, европске државе сносе одговорност за недавну прошлост. Тај терет одговорности држаће их изван европске породице народа све док се са њим не суоче и док не престану са оспоравањем. Зато његова политичка историја садржи све елементе етичког приступа и интелектуалне историје, јер Европу посматра као колектив, као збир појединаца који имају своје ставове, уверења, идеологију. То је тема његових студија, хладни рат, левица, односно XX век у свој својој сложености. То никако није историја држава, нити историја Запада. Откривањем интелектуалаца са периферије, Џат је сазнавао периферију, његова Европа је као можда код никога другог јединствен континент у раздобљу њене највеће раздвојености. Посебно га занима однос Европе и историје, јер се у духу измишљања традиције увек може изградити пожељнија прошлост, а само ако „европска прошлост настави да испуњава европску садашњост опомињућим значењем и моралном сврховитошћу, онда ће и свака следећа генерација имати шта изнова да научи.““33 Покретањем питања табуа, и после сјајне критике за свој рад, Џат је отворио могућност сопствене друштвене улоге, афирмисани интелектуализам захтевао је ангажман.

\section{Два Тонија Џата - постхладноратовска перспектива}

Тони Џат као историчар критикује интелектуалце који вером у утопију желе да мењају свет, али Џат као интелектуалац верује у утопију - да је свет могуће променити. И то исти Џат који само неколико година раније напада Хобсбаума због књиге индикативног наслова Како променити свет? ${ }^{34}$ Међутим, погрешно би и крајње анахроно било нападати Џата за недоследност али је посебно питање њему наметнуто, у чему се разликује од „својих“ интелектуалаца, које толико критикује? Његова критика настајала је кроз само дело, кроз научну методологију и јасну доследност, формиран је и опстајао као историчар са ставом, из чијег се дела јасно уочава промишљање предмета истраживања. ${ }^{35}$ Његов ангажман заправо почиње кроз саму науку, као задатак и одговорност према историчаревој струци. Посебно се истиче борба за интерпретацију и културу сећања, како оно што прети да буде заборављено не би остало потиснуто у прошлости као да се није ни десило. При том на уму има пре свега холокауст и антисемитизам, инсистирајући на тежој формулацији, истребљењу и тишини о злочину. Доследно и упорно подсећа на

\footnotetext{
${ }^{33}$ Tony Judt, Postwar. A History of Europe Since 1945, London 2007 (2005¹), 831, passim.

${ }^{34}$ Чланак под називом Eric Hobsbawm and the Romance of Communism првобитно је објављен у The New York Review of Books у новембру 2003, касније поново публикован у Reappraisals. Reflection on the Forgotten Twentieth Century, 116-128. Кад је Хобсбаум у питању реч је о већ цитираној књизи, видети фусноту број 10.

35 Томе у прилог говоре студије где је он био један од уредника: Resistance and Revolution in Mediterranean Europe 1939-1948, (ed. Tony Judt), London 1989; The Politics of Retribution in Europe: World War II and its Aftermath (eds. Istvan Deak, Gross Jan, Tony Judt), Princeton 2000; Language, Nation, and State: Identity Politics In A Multilingual Age (eds. Tony Judt, Denis Lacorne), New York 2004; With Us Or Against Us: Studies in Global Anti-Americanism (eds. Tony Judt, Denis Lacorne), New York 2005.
} 
мисао Хане Арент о баналности зла. ${ }^{36}$ Критику је посматрао као дужност интелектуалца, терет одговорности, али критику која не може опстати без реализације, јер ангажовани интелектуалац мора знати како да знање спроведе у дело, „филозофи су тумачили свет, а наш задатак је да га променимо.“37 Полази од чињенице да је савремени свет у социјално-економском погледу довео до највећег раслојавања у својој историји, богати никад нису били богатији, сиромашни сиромашнији. Нема принципа хуманости уколико нема левице, а левице нема без теорије, без марксизма. То не значи да је напрасно постао марксиста, већ сматра да без радикалне нема ни умерене левице. Ту упада у својеврсну замку анахронизма, jep је спреман да екскулпира теоријски марксизам од грешака историјског стаљинизма. Дискурс о нужности марксизма уследио је након пропасти комунизма, што саму теорију поставља у другачији историјски контекст. Нестанком историјског стаљинизма теоријски марксизам ослобођен је оптужби за тоталитаризам. Због тога Џат не признаје поређења са интелектуацима које је критиковао.

Основно оружје његове борбе био је интелектуализам, а главно гласило, посредством Тимоти Гартона Еша, часопис The New York Review of Books, где га је током читаве прве деценије XXI века, могуће пратити као историчара и као есејисту како то Еш истиче. ${ }^{38}$ Пажњу је усмеравао на амерички интервенционизам и израелско-палестински сукоб. Док су га у првом случају преокупирали посрнули интелектуалци, ционизам је представљао питање порекла и идентитета. Критика израелске политике и заступање идеје о две државе, не само да је условило његово одрицање од ционистичког покрета коме је у младости припадао, већ је представљало и известан терет одговорности, заједно са свешћу колико је вредан његов јеврејски глас. Устајао је и против позивања на холокауст, тврдећи да је оправдање политике историјом условило обесмишљавање најстрашнијег злочина $\mathrm{XX}$ века и његову потпуну релативизацију. Оспорава идеју јеврејске државе, истичући мултиетничност и мултикултуралност као принципе на којима почивају савремена демократска друштва, нападајући етнорелигиозни критеријум држављанства. Проучавао је идеју демократије, позивање у име демократије приликом интервенционизма, оптужујући либералне интелектуалце да теоретишу рат уместо да пропагирају мир. ${ }^{39}$ Током последње деценије приметно инсистира на непожељној прошлости и нестанку левице. Оптерећује га интелектуални конформизам, унесрећује га лаж, због чега се враћа питању истине и филозофским критеријумима њене спознаје. Изазива буру емоција текстом о Румунији између историје и Европе, подсећањем на прошлост које нико не жели да се сећа, на односе према Јеврејима, на фашистичке интелектуалце нечисте савести, на ужасну

\footnotetext{
${ }^{36}$ T. Judt, From the House of the Dead: On Modern European Memory, The New York Review of Books, Oct. 2005; T. Judt, The 'Problem of Evil' in Postwar Europe, The New York Review of Books, Febr. 14, 2008.

${ }^{37}$ Toni Dzad, Teško zemlji, 170-173.

${ }^{38}$ Timothy Garton Ash, Tony Judt (1948-2010.), The New York Review of Books, Sept. 30, 2010.

${ }^{39}$ T. Judt, On Intellectuals and Democracy, The New York Review of Books, Mart 22, 2012; T. Judt, Bush's Useful Idiots, London Review of Books, Vol. 28, No. 18, London 2006, 3-5; T. Judt, Israel: The Alternative, The New York Review of Books, Oct. 23, 2003.
} 
економску заосталост. Преиспитује блеровски лабуризам, оптужујући га за потпуни раскид са лабуристичким идејама и социјалдемократским принципима. ${ }^{40}$ Континуирано је изучавао историју европске идеје фокусирајући се на прагматизам као једини успешан метод европске интеграције, који по њему током последње деценије XX века губи на значају, а сама Унија почиње да се окреће идеолошкодемагошком утемељењу свог опстанка. Занима га европска социјалдемократија којој одаје признање за креирање хуманијег окружења у односу на САД. Идеју европског јединства посматра као успели експеримент глобализације, као рушење граница и преобликовање замишљених заједница, без обзира на тешкоће. ${ }^{41}$

Последње две године Џатовог живота, представљају период најжешће борбе. Тада је књиге осмишљавао, писао их у свом уму ноћу, опхрван боловима и суочен са болешћу која је водила у страшну смрт. Дању је те осмишљене параграфе диктирао сарадницима, успевши да на тај начин креира три књиге. Иако се тематски и жанровски веома разликују, садрже снажну етичку црту, до крајности изражен интелектуализам и ангажман који тежи великој истини, револуцији која ће срушити свет. Џат сматра да је постојећи неолиберални поредак делегитимисао сам себе, вапијуће подсећа да је у комунизму најстрашније оно што следи после њега и да рат попут расизма, нуди јасне изборе. ${ }^{42}$ Устаје против система у којем више не постоје универзалне вредности. У аутобиографском романескном штиву Колиба сећања још једном подсећа на врлину и снагу личне одговорности, даје на сопственом случају пример једног достојанственог интелектуалног прегнућа у XX веку, који није пропустио да направи избор, сноси одговорност и ангажује се на принципу етичког критеријума. Подсећа да су најважније вредности духовне и презире материјализам данашњег света. ${ }^{43}$ Последња књига, штампана постхумно, конципирана је у виду разговора које је имао са Тимоти Снајдером, као комбинација личне и породичне историје, искуства у XX веку уклопљена у искуства о XX веку, његовог промишљања свог животног предмета истраживања. Потпуно је и нескривено директан и личан, предајући се суду јавности. Док је Тешко земљи намењена младима, као водич и охрабрење, у Размишљањима о XX веку подвргао је суду стручне јавности свој историографски рад, интелектуализам и ангажман без предрасуда о властитим грешкама и ограничењима. ${ }^{44}$

\footnotetext{
${ }^{40}$ T. Judt, Reappraisals, 219-232; 249-267.

41 T. Judt, A Grand Illusion? An Essay on Europe, New York-London 2011 (1996 ${ }^{1}$ ); T. Judt, Europe vs. America, The New York Review of Books, Febr. 10, 2005; T. Judt, The Past is Another Country: Myth and Memory in Postwar Europe, Daedalus, Vol. 121, No. 4 (Fall 1992.), 83-118; T. Judt, Nineteen Eighty Nine: The End of Which European Era?, Daedalus, Vol. 123, No. 3 (Summer 1994.), 1-19; T. Judt, The Rediscovery of Central Europe, Daedalus, Vol. 119, No. 1 (Winter 1990.), 23-54.

${ }^{42}$ Toni Dzad, Teško zemlji, 106-107; 122-123.

${ }^{43}$ Toni Dzat, Koliba sećanja, Beograd $2011\left(2010^{1}\right)$.

${ }^{44}$ Tony Judt, Timothy Snyder, Thinking the Twentieth Century, New York 2012.
} 
„Готово је са дојучерашњим светом, готово за свагда““45 рекао је још један велики интелектуалац XX века, Лисјен Февр. Није као Тони Џат промишљао кризу друштвено-политичког система, говорио је о историјском методу. Џатово историографско дело поставља питање одговорности историчара према степену примењене егзактности, тенденциозности и селекцији. Историчар барата чињеницама, али је избор чињеница и начин интерпретације остављен његовом суду који се базира на односу објективних и субјективних критеријума. Историографија без теорије за Џата као и за аналисте није опција, потребна је проблемска историографија, која у тежњи да објасни испољава захтев за разумевањем. Историчар није неми посматрач прошле стварности, већ неко ко са моралним ауторитетом доноси суд, ко прави избор. Пред њим је следеће питање најважније, доследност. Историчар се не може поводити за трендовима, јер најбоље разуме пролазност епоха. Такав историчар се неминовно налази пред одабиром јавне улоге, која наглашава његову улогу интелектуалца садашњице за разлику од историчара зароњеног у прошлост, али интелектуализам којим разуме и спознаје савремене проблеме резултат је његовог стручног искуства. Зато јавни ангажман мора бити ограничен на когнитивно поље научне кредибилности. Тони Џат је направио неколико избора, најпре опредељењем за тему својих студија, одабравши најкрупније питање свог века, према коме је заузео лични став, али и приступао на крајње оригиналан начин. Његово трагање за методом условило је промишљање историје, тежило јединствености, морао је по сваку цену бити другачији. Саме студије интелектуалне историје, како је назива, одваја од историје идеја простим критеријумима посматрања које сам намеће: избор, одговорност, ангажман. Залаже се за етички приступ историографији, као посебни метод историјске струке, који сам афирмише. За Џата историја није некропола чињеница, већ начин мишљења, спознаје света, које инкорпорира у своје искуство, као човек окружен књигама у глави и простору око себе. У веку идеологија историографија је у служби идеологија. Задатак историчара је прометејска амбиција неприпадања и веровања искључиво у сопствени разум, како то Џат истиче, моралист је онај који говори истину, тишина је разлика између интелектуалца и моралисте. ${ }^{46}$ Ослободити се вере, метанаратива али снажити уверења и истрајавати. Питање метода зато је кључно у историографији XX века, јер упућује на избор и свесно и одговорно (не)припадање. У потрази за методом, као и Албер Ками, Џат се свесно упушта на пут којим се ређе иде, на ком га чека осуда и напад са свих страна, али одабир етичког метода и неприпадање идеологијама постају му једина нада објективности. Попут Золе, Камија и Џата, интелектуалац је сам на овом свету, али „нисмо изгубили ништа ако сачувамо дух. Објаснимо свет свету.“47

\footnotetext{
45 Лисјен Февр, Борба за историју, Београд 2004, 66.

${ }^{46}$ T. Judt, The Burden of Responsibility, 121-124.

${ }^{47}$ Февр, Борба за историју, 66.
} 


\section{Литература:}

Arent, Hana, Izvori totalitarizma, Beograd 1998

Ash Garton, Timothy, Tony Judt (1948-2010.), The New York Review of Books, Sept. 30, 2010

Benda, Julien, Izdaja intelektualaca, Zagreb 1997

Берк, Питер, Франиуска историјска револуција: школа „Анала“ 1929-1989, Нови Сад 2011

Deak, Istvan, Jan Gross, Judt Tony, eds, The Politics of Retribution in Europe: World War II and its Aftermath, Princeton 2000

Февр, Лисјен, Борба за историју, Београд 2004

Fukujama, Frensis, Kraj istorije i poslednji čovek, Podgorica-Banja Luka-Beograd 2002

Hobsbawm, Eric, After the Cold War, London Review of Books, Vol. 34, No. 8, London 2012

Hobsbawm, Eric, How to Change the World. Reflections on Marx and Marxism, London 2011

Hobsbaum, Erik, Interesantna vremena. Jedan život u dvadesetom veku, Podgorica 2005

Judt, Tony, Past Imperfect. French Intellectuals, 1944-1956, Barkley-Los Angeles-Oxford 1992

Judt, Tony, Snyder Timothy, Thinking the Twentieth Century, New York 2012

Judt, Tony, A Clown in Regal Purple: Social History and the Historians, History Workshop Journal, No. 7, Oxford 1979

Judt, Tony, What is Living and What is Death in Social Democracy? The New York Review of Books, December 17, 2009

Judt, Tony, La reconstruction du parti socialiste: 1921-1926, Paris1976

Judt, Tony Socialism in Provence 1871-1914. A Study in the Origins of the Modern French Left, New York-London 2011

Judt, Tony Marxism and the French Left. Studies of Labour and Politics in France, 1830-1981, New York-London 2011

Judt, Tony, The Development of Socialism in France: The Example of the Var, The Historical Journal, Vol. 18, No. 1, Cambridge 1975

Judt, Tony, The Origins of Rural Socialism in Europe: Economic Change and the Provençal Peasantry, 1870-1914, Social History, Vol. 1, No. 1 (Jan. 1976.)

Judt, Tony, Socialism in the French Countryside: A Reply, The Historical Journal, Vol. 21, No. 3 (Sep. 1978.)

Judt, Tony, The French Socialist and the Cartel de Gauches of 1924, Journal of Contemporary History, Vol. 11, No. 2/3 (Jul. 1976.)

Judt, Tony, The Burden of Responsibility. Blum, Camus, Aron, and the French Twentieth Century, Chicago-London 1998

Judt, Tony, Paris Was Yesterday, New York Review of Books, March 11, 2010

Judt, Tony, "We Have Discovered History": Defeat, Resistance, and the Intellectuals in France, The Journal of Modern History, Vol. 64 (Dec. 1992.)

Judt, Tony, Reappraisals. Reflection on the Forgotten Twentieth Century, New York 2008

Judt, Tony, Postwar. A History of Europe Since 1945, London 2007

Judt, Tony, ed. Resistance and Revolution in Mediterranean Europe 1939-1948, London 1989

Judt, Tony, Lacorne Denis, eds, Language, Nation, and State: Identity Politics In A Multilingual Age, New York 2004

Judt, Tony, Lacorne Denis, eds, With Us Or Against Us: Studies in Global Anti-Americanism, New York 2005 
Judt, Tony, From the House of the Dead: On Modern European Memory, The New York Review of Books, Oct, 2005

Judt, Tony, The 'Problem of Evil' in Postwar Europe, The New York Review of Books, Febr. 14, 2008

Judt, Tony, On Intellectuals and Democracy, The New York Review of Books, Mart 22, 2012

Judt, Tony, Bush's Useful Idiots, London Review of Books, Vol. 28, No. 18, London 2006

Judt, Tony, Israel: The Alternative, The New York Review of Books, Oct. 23, 2003

Judt, Tony, A Grand Illusion? An Essay on Europe, New York-London 2011

Judt, Tony, Europe vs. America, The New York Review of Books, Febr. 10, 2005

Judt, Tony, The Past is Another Country: Myth and Memory in Postwar Europe, Daedalus, Vol. 121, No. 4 (Fall 1992.)

Judt, Tony, Nineteen Eighty Nine: The End of Which European Era?, Daedalus, Vol. 123, No. 3 (Summer 1994.)

Judt, Tony, The Rediscovery of Central Europe, Daedalus, Vol. 119, No. 1 (Winter 1990.)

Dzad, Toni, Teško zemlji, Beograd 2011

Dzat, Toni, Koliba sećanja, Beograd 2011

Kolakovski, Lešek, Glavni tokovi marksizma I, II, III, Beograd 1985

Moyn, Samuel, Intellectuals, Reason, and History: In Memory of Tony Judt, H-France Salon, Volume 4, Issue 2, No. 3

Moyn, Samuel, On the Genealogy of Morals, The Nation, 16. April 2007 


\title{
ENGAGED INTELLECTUALISM AND THE ETHICS OF RESPONSIBILITY HISTORIOGRAPHY WORK OF TONY JUDT
}

\begin{abstract}
Summary
The paper analyzes the historiography work of an American historian of the English origin, Tony Judt (1948-2010), focusing on the specifics of his approach to historiography, intellectual history, and the criteria of ethical selection. There were distinguished three stages of his work, which led to the structure of the work: the study of Marxism, intellectual history, and public engagement. There was especially analyzed his relationship to Marxism and the distinction ideas of so called historical Marxism and theoretical Stalinism, on which basis he accused leading French post-war intellectuals of their affection for totalitarianism. During the last phase, the focus was on Judt's critique of the American interventionism and Jewish policy in Palestine, and especially on his critique of the values of the contemporary world, which brought him back to the ideas of theoretical Marxism. Judt's approach to historiography through the intellectual history tended to de-ideologization of science. The critique of Marxism under the burden of the Soviet paradigm was conditioned by the idea of Leszek Kolakowski that Marxism as an ideology could not exculpate errors of the Communist practice. Therefore he reprehended the postwar generation of French intellectuals led by Sartre for not distancing themselves on time from the Communist ideas, i.e. from their own past. However, through the PostCold War perspective Judt took positions similar to the positions of the criticized intellectuals, with the main difference that it was from an era which, besides the theoretical Marxism, did not have a paradigm in a form of historical Stalinism, which should be distanced from. Judt was never a Marxist, and his idea of the necessity of Marxism, as an alternation which should be distanced from, represented the view that without radical (revolutionary) left wing, it was not possible to have a moderate left. He was one of the loudest critics of neo-liberalism, which he attempted to de-legitimize in his claim to have more humane world.
\end{abstract}

Keywords: Tony Judt, historiography, the twentieth century, Marxism, the Left, the intellectual history, French intellectuals. 